\title{
Prevention and Enforcement Efforts against Embezzlement of Car Rental Crime in Police Resort City of Semarang (Case Study No. Bp / 87 / K / Bap / VII / 2018 / Reskrim on 6 June 2018)
}

\author{
Insan Al Ha Za Zuna Darma Illahi ${ }^{1}$, Ira Alia Maerani ${ }^{2}$ and Aryani Witasari ${ }^{3}$
}

Abstract. This study aims to identify and explain the efforts to control and enforcement of laws against the Embezzlement Of Car Rental Crime in Police Resort City of Semarang, to determine the enforcement of laws against the Embezzlement Of Car Rental Crime in the city of Semarang, and to know the constraints and find solutions in an effort to prevention and law enforcement against criminal acts of embezzlement car rental in Police Resort City of Semarang.

This study uses empirical juridical approach or legal research Sociological with embezzlement case study specification car in Semarang. Data were collected from documents and interviews with investigators Vice Unit I Resum Sat Reskrim Police Resort City of Semarang to then analyzed using qualitative analysis, and then concluded.

The results showed that law enforcement is often done by the City Police of the Semarang to the crime of embezzlement car rental, while the factors that are the cause has not done of law enforcement due to limits in the Book of the Law of Criminal Law and the crime on complaint, therefore efforts conducted by the City Police of the Semarang can be divided into three attempts pre-emptive, preventive and repressive, these efforts are sometimes subject to constraints such as the difficulty of giving meaning to the people, cars rented a car loan, easy to hand over vehicles to consumers.

Keywords: Reduction Efforts; Law Enforcement; the Crime of Embezzlement.

\section{Introduction}

Means of transport is one important element in the life of modern society one of them in Indonesia. Even one sign of progress in a society is a smooth transport system present in an area. It makes infrastructure, transport itself is an important part that can not be separated for the people of Indonesia as a developing country in the world and for the continuation of community.

In the process of development of transportation seen a reciprocal influence between the development of civilization and trading activities of society with the development of transportation technology. Effect of different transport among one region to another. There are areas where people become static in the economy due to lack of good performance of the transport system that connects the outside world, so that the relatively low level of public life and is difficult to be improved. ${ }^{4}$

The high demand for transportation coupled with the low ability of people to buy a private vehicle rental business resulting / private vehicle rental business has increased

\footnotetext{
${ }^{1}$ Student of Master of Law, Universitas Islam Sultan Agung Semarang and Bussinessman, Email: damazuna@yahoo.com

${ }^{2}$ Lecturer of Master of Law, Sultan Agung Islamic University (UNISSULA), Semarang

${ }^{3}$ Lecturer of Master of Law, Sultan Agung Islamic University (UNISSULA), Semarang

4 D.-ing. M.Yasmin Jinca, MSTr, Transportasi Laut Indonesia Analisis Sistem dan Studi Kasus, Brilian Internasional, Surabaya, 2011, p 5
} 
significantly in recent years. Business opportunities in the field of car rentals considered more promising because the potential demand is growing as the growth of the national economy after the improvement in the Indonesian economy at the beginning of 2014. The data obtained from Tempo 1.5 million vehicles, the company's operations in Indonesia, 415 thousand units of a rental car. $^{5}$ It is a parameter that interest and demand for vehicle rental / rental is still high in Indonesia, including one in the city of Semarang.

It is unfortunate in practice, after all the convenience provided by the car rental service was still just a car rental business became the target or targets of crime by elements who are not responsible. This was shown by the frequent occurrence of criminal fraud and embezzlement suffered by the owner of the car rental services made by users of car rental services with the mode does not return, sell or mortgage a car rented from a car rental company, resulting in a car rental company materially harmed. This criminal offense also occurred in Semarang which could be categorized as the Big City.

The emergence of criminal offenses committed tenants for goods belonging to the owner rented a car rental because of misuse or abuse of the right of trust where the crime of embezzlement in the set the provisions of article 372 of the Criminal Code, which reads:

"Whoever intentionally and unlawfully claimed as your own (Zich Toeeigenen) goods something wholly or partly belonged to someone else, but it is in his power not because of evil, threatened, for embezzlement, with a minimum of four years or a fine many sixty rupiah ". 6

Despite having been threatened with the threat of jail long enough, but there are still many who dare to commit embezzlement rental car. This has led the authors to examine the factors in society that led to the crime of embezzlement is still the rental vehicle as well as solutions and remedy what can be done to prevent more criminal acts of embezzlement of this rental car. So that ultimately protect the interests of the community as the most in need of this rental car service.

Thus the authors were interested to pick up and examine more of the problems related to the embezzlement of vehicles belonging to a rental in particularly in the city of Semarang with title "Prevention And Enforcement Efforts Against Embezzlement Of Car Rental Crime In Police Resort City of Semarang".

Based on the description above, it can then be formulated as a problem following: How to efforts to control and enforcement of laws against the Embezzlement Of Car Rental Crime in Police Resort City of Semarang?; How constraints and solutions in prevention and law enforcement efforts against criminal acts rental car in Police Resort City of Semarang?

\section{Research Methods}

This research approach is a Juridical Empirical or sociological law research. Empirical legal research methods that examine or sociological laws of social behavior to the law. Methods This study provides very clear explanation of the behavior of citizens to the law

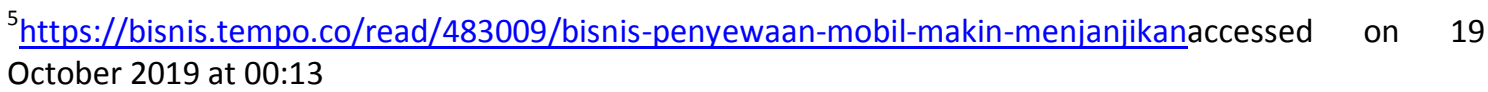

${ }^{6}$ Moeljatno, Kitab Undang-Undang Hukum Pidana, Bumi Aksara, Jakarta, 2011, p. 132
} 
so that no one intake of official policy. ${ }^{7}$

Develop this study, the approach used is qualitative normative approach, which describes the data contained in statements or writings not use numbers. Normative methods of research that uses a variety of data such as legislation and regulations, the opinions of the scholars, and court decisions. Qualitative way ie without statistical formulas, in order to obtain a clear and comprehensive picture. The data obtained are qualified to study and understand all existing data is analyzed by interpreting using qualitative normative method.

\section{Results And Discussion}

\subsection{Law Enforcement Efforts Against Crime Embezzlement Car Rental In Police Resort City Of Semarang}

The criminal acts of embezzlement arranged in book II, Chapter XXIV of the Code of Penal (Penal Code), entitled "embezzlement". The criminal acts of embezzlement regulated in several articles, namely Article 372 of the Criminal Code to Article 377 of the Criminal Code which read:

- Article 372: "Whoever intentionally and unlawfully have the goods, completely or partially belongs to someone else, and only to him not as a crime punishable by imprisonment for ever four years or a fine of up to 15 times sixty rupiah".

- Article 373: "The act described in Article 372, when darkened instead of cattle and cost no more than two hundred and fifty thousand rupiah, punishable as embezzlement mild, with imprisonment for ever three months or a fine of up to 15 times sixty rupiah",

- Article 374 : "Embezzlement by persons to hold the goods for his own or because of their work or as a reward money, was sentenced to imprisonment for a term to five years".

- Article 375 : "Embezzlement committed people to him had to be given to be kept, or by a guardian, keeper, administrators, people who run wills, official charities or foundations for goods that is on them because of their office such that, be punished with imprisonment for ever six years ".

- Article 376 : "The rules in Article 376 applies to the crimes described in this chapter". The offenses listed in Article 372 the Code of Penal (Penal Code) is a criminal offense subject. That is, all kinds of embezzlement must meet a core part of Article 372 plus other core parts. Embezzlement criminal offense is an offense in a crime against a person or vermogensdelicten wealth as stipulated in Article 372 through Article 377 of the Code of Penal (Penal Code) above.

In the context of law enforcement, need to examine the opinion of experts, including criminal cases of embezzlement of car rental in one of the cases in this study. According to the United Nyoman Putra Jaya, all parties, especially among the legal community needs to think and fight for a reform in the field of law enforcement. ${ }^{8}$ Law enforcement is given a broader meaning, not only concerning the implementation of the law (law

\footnotetext{
${ }^{7}$ I Made Pasek Diantha, Metodologi Penelitian Hukum Normatif Dalam Justifikasi Teori Hukum, Prenada Media Group, Jakarta, 2016, p 12

${ }^{8}$ Nyoman Serikat Putra Jaya, Kapita Selekta Hukum Pidana, Bp UNDIP, Semarang, 2005, p 49
} 
Enforcement) and socialization.

According Asshiddiqie cited by Lawrence Arliman s, that: Law enforcement is doing efforts to the enforcement process or the functioning of legal norms significantly as a code of conduct in traffic or legal relations in society and state. In terms of the subject in a broader sense, the law enforcement process that involves all subjects of law in any legal relationship. Anyone who runs normative rules or do something or not do something by basing itself on the rule of law norms, meaning he is running or enforce the rule of law. Narrow sense, law enforcement only be interpreted as an attempt of certain law enforcement officials to guarantee and ensure that a legal rule as it ought to. In ensuring the rule of law, if necessary, ${ }^{9}$

According to Riduan Syahrani quoting the opinion of Satjipto Rahardjo that: Law enforcement is an attempt to realize the ideas of justice, rule of law and social benefit into reality. The ideas of the law are the thoughts lawmaking body as defined in regulation legislation. The process embodiment of ideas that is the essence of law enforcement. $^{10}$

In law enforcement against criminal acts of embezzlement rental car, officers as investigators have carried out the appropriate law enforcement Regulation Legislation No. 8 of 1981 About the Code of Criminal Procedure. That investigation by Police Report No. LP / B / 226 / V / 2018 / CENTRAL / RESTABES Semarang, dated May 25, 2018, the Investigation Order Letter No. SP. Fingerprint / 135 / VI / 2018 / Reskrim, June 6, 2018. Then the Notice At the start of Investigation No. B / 87 / IV / 2018 / Reskrim, June 6, 2018. The results of the investigation has been carried out the seizure of the car rental agreement and letter chronological made by the offender. ${ }^{11}$

Efforts to control and enforcement of laws against the Embezzlement Of Car Rental Crime in the Big City Resort Semarang police forces in order to minimize the occurrence of crime, has carried out several steps. So prevention and law enforcement efforts carried out within three (3) forms, namely; The first is the reduction in pre-emptive, preventive and response handling it be repressive, which is described as follows: ${ }^{12}$

- Pre-emptive efforts; Actions by giving advice to employers rental car at the time of release the car to be more careful when handing the car to tenants.

- Preventive efforts

- Run prevention function of the City Police in Semarang by giving messages kabtibmas message to the manager of the rental car, to be more careful when releasing the car to prospective customers.

- To provide guidance to organizations and communities and to involve the public to participate would prevent the occurrence of embezzlement in the region by creating an association of rental cars produser, so that with the container car rental entrepreneurs can exchange information.

- Enlighten the law to the public and mass organizations that act darken the car is a criminal offense and punishable by criminal law.

\footnotetext{
${ }^{9}$ Lawrence Arliman s, Peoples, Law Enforcement and Awareness, Cet. 1, Deepublis, Yogyakarta, 2015, $p$ 12

${ }^{10}$ Marwan Effendi, Kapita Selekta Hukum Pidana, Jakarta: Referensi, 2011, p 26

${ }^{11}$ Interview with Bripka Abdullah Hidayat, SH, MH, Assistant Investigator Criminal Investigation Unit I Resum Sat Reskrim in Polrestabes Semarang, held on February 20, 2020

${ }^{12}$ Ibid.
} 
- Repressive efforts; Efforts investigators in combating the crime of embezzlement car rental with repressive measures, such as: Receive reports from victims, then follow up by conducting a series of investigations; Summon the suspects for questioning; Conduct an examination of the suspect; Detaining suspects; Doing seizure of evidence; Delivers evidence and suspects to the State Attorney Semarang.

\subsection{Constraints and Solutions In Prevention and Law Enforcement Efforts Against The Embezzlement Of Car Rental Crime In Police Resort City Of Semarang}

Based on prevention and law enforcement efforts against the crime of embezzlement is still a lot of the discovery of the constraints inhibiting, among others: ${ }^{13}$

- Their limits must be obeyed and implemented by the police in accordance Act No. 8 of 1981 About the Code of Criminal Procedure (Criminal Procedure Code) in the investigation, namely the arrest, seizure, detention and presence to a complaint first. Therefore the police are more active and play a role reviewing and asking the community through a legal entity or association, if there is a problem that contradicts the law in carrying out the car rental business as well as their problems evasion a criminal offense rental car was going.

- Difficult to give the sense that the car rental business is not so simple, because the average victims of embezzlement cars are people who still lack information on how to release the car in a safe way. The obligation to have a legal entity before starting a car rental business is the best alternative must have people who want to start a car rental business and the public were minimal for information about the car rental business.

- Lack knowledge and understanding of the law enforcement process against the crime of embezzlement by the managers of the rental car, which is the average car is a car bought on credit in Leasing. Though BPKB a requirement Formal form of ownership that can be given. Therefore the police officer must often socialize how the process of law enforcement against criminal acts of embezzlement to the public owner of the car rental.

- The young boy who runs a car rental can simply leave the car to the perpetrators of embezzlement of cars without including the witness at the time of delivery of the car, and without a written agreement between the tenant and the rent, so that at the time of reporting the evidence of witnesses, mail or the instructions are not there making it difficult for investigators when dealing with the case. So that the police must often provide an appeal to the owners of rental car how it should be the owner of a car rental rents cars by completing the letter of the lease agreement and ownership papers before the car is rented.

- Unknown perpetrators, the use of false identities are also common and has a serious impact on rental cars. Therefore, through the strengthening of community among members or between the car rental community with other associations in the city, where one of them sharing information with fellow members of the association, if there is someone suspicious customer, looking for background information and or the customer. 


\section{Closing}

\subsection{Conclusion}

Based on the above discussion, to problems in this study, it can be concluded that:

- Law enforcement based on a police report number: LP / B / 226 / V / 2018 / CENTRAL / RESTABES SMG, dated May 25, 2018. In case this is not done the searches, but have made seizure of three (3) letters bundles rental agreement on 6 January 2017; car rental agreement letter on February 1st, 2017, letter on car rental agreement March 1,2017 , and 1 (one) letter chronological made by the suspect dated 27 April 2017.Prevention efforts undertaken by the authorities of the City Police Semarang in law enforcement against criminal acts of embezzlement rental car is an effort to preemptive, preventive and repressive.

- constraints in prevention and law enforcement efforts against the crime of embezzlement rental car that is, the limitations that must be complied with and implemented law enforcement officers, the difficulty of giving meaning to the community, Most rented car is the car loan, simply leave vehicles to consumers, does not know the perpetrator.

\subsection{Suggestion}

- To The Police Resort City of Semarang should be aggressively counseling to entrepreneurs car rental employers with increased security in running a car rental business related to installation of GPS or other tracking. So that helped investigators as easy to find a car rental darkened. The second provides guidance to be careful in renting a car, especially to new tenants who previously unknown or new customers and tenants who rent a car in large quantities at once.

- For The Entrepreneur Rental should do increase safety standards in service lease cars that they have through standard procedures, for example the delivery of bail and other goods as collateral, examine carefully the tenant and customer good of a sign of identity and profile of the tenant to ensure tenants not criminals and have the intention to commit the crimes. In addition, it is expected the car rental weeks to cooperate with the party of the Semarang City Police or the nearest police ranks when there is a criminal act so that the disclosure and handling can do the journey well.

\section{References}

[1] D.-ing. M.Yasmin Jinca, MSTr, Transportasi Laut Indonesia Analisis Sistem dan Studi Kasus, Brilian Internasional, Surabaya, 2011

[2] I Made Pasek Diantha, Metodologi Penelitian Hukum Normatif Dalam Justifikasi Teori Hukum, Prenada Media Group, Jakarta, 2016

[3] Laurensius Arliman s, Penegakan Hukum dan Kesadaran Masyrakat, Ed. 1, Deepublis, Yogyakarta, 2015

[4] Marwan Effendi, Kapita Selekta Hukum Pidana, Jakarta: Referensi, 2011

[5] Moeljatno, Kitab Undang-Undang Hukum Pidana, Bumi Aksara, Jakarta, 2011

[6] Nyoman Serikat Putra Jaya, Kapita Selekta Hukum Pidana, Bp UNDIP, Semarang, 2005

[7] https://bisnis.tempo.co/read/483009/bisnis-penyewaan-mobil-makin-menjanjikan 